\title{
LAYANAN BIMBINGAN KELOMPOK DENGAN TEKNIK SELF- MANAGEMENT TERHADAP PROKRASTINASI AKADEMIK
}

\author{
Hadei Yoga Swara ${ }^{1}$, Supardi ${ }^{2}$, Padmi Dhyah Yulianti ${ }^{3}$. \\ ${ }^{1,2,3}$ Program Studi Bimbingan dan Konseling, Fakultas IImu Pendidikan, \\ Universitas PGRI Semarang \\ e-mail: Yogaswara380@gmail.com 1 , supriadi12@gmail.com². \\ dyah13@gmail.com ${ }^{3}$
}

\begin{abstract}
ABSTRAK
Penelitian ini bertujuan untuk mengetahui pengaruh layanan bimbingan kelompok dengan teknik self-management terhadap prokrastinasi akademik. Penelitian ini merupakan penelitian kuantitatif melalui metode penelitian True Experimental Design dengan model Pre-test Post-test Control Group Design. Populasi dalam penelitian ini adalah siswa kelas XI IPA SMA N 11 Semarang dengan jumlah 252 siswa. Kelas XI IPA 2 adalah kelas yang dipergunakan untuk tryout sebanyak 36 siswa. Sampel dalam penelitian yaitu 20 siswa kelas XI IPA 4 dan XI IPA 5 yang diambil dengan menggunakan teknik sampling cluster random sampling. Alat pengumpul data yang dipergunakan adalah skala prokrastinasi akademik. Berdasarkan hasil analisis data uji hipotesis diperoleh $t_{\text {hitung }}=$ $\pm 4,561$ Selanjutnya dikonsultasikan dengan $t_{\text {tabel }}$ dengan taraf signifikansi $5 \%(0,05)$ yaitu 2,101 . Hal tersebut menunjukan bahwa $t_{\text {hitung }}= \pm 4,561>t_{\text {tabel }}=2$, 101. Atas dasar perhitungan tersebut maka hipotesis alternatif $(\mathrm{Ha})$ yang berbunyi "ada pengaruh layanan bimbingan kelompok dengan teknik self-management terhadap prorastinasi akademik siswa kelas XI IPA SMA N 11 Semarang" diterima kebenarannya pada taraf signifikansi 5\%. Dengan demikian menunjukan bahwa ada pengaruh layanan bimbingan kelompok dengan teknik selft-management terhadap prokrastinasi akademik.
\end{abstract}

Kata Kunci : Bimbingan Kelompok, Teknik Self-Management, Prokrastinasi Akademik

This study aims to determine the effect of group guidance services with self-management techniques on academic procrastination. This research is a quantitative study through the True Experimental Design research method with the Pre-test Post-test Control Group Design model. The population in this study were students of class XI IPA SMA 11 Semarang with a total of 252 students. Class XI Science 2 is a class that is used for tryouts of 36 students. The samples in this study were 20 students of class XI IPA 4 and XI IPA 5 taken using cluster random sampling technique. The data collection tool used is the academic procrastination scale. Based on the results of the analysis of the hypothesis test data obtained tcount $= \pm 4,561$ Subsequently consulted with ttable with a significance level of $5 \%$ (0.05), namely 2.101. This shows that tcount $= \pm 4,561>$ ttable $=2,101$. On the basis of these calculations, the alternative hypothesis $(\mathrm{Ha})$ which reads "there is an influence of group guidance services with self-management techniques to the academic progress of students of class XI IPA SMA 11 Semarang" is accepted at the significance level of 5\%. Thus it shows that there is an influence of group guidance services with selft-management techniques on academic procrastination.

Keywords : Group Counseling, self-management techniques, academic procrastination 


\section{Pendahuluan}

Dalam proses perkembangan individu atau siswa, terdapat beberapa fase yang harus dilewati secara bertahap, sistematis dan memiliki jangka waktu tertentu. Tidak terkecuali siswa Sekolah Menengah Atas (SMA) yang digolongkan sebagai remaja. Menurut Jahja (2011:31) dari Hasil Rapat Kerja UKK Pediatric Sosial di Jakarta, yaitu siswa memasuki masa sekolah pada usia 6-18/20 tahun. Dimana bila dilihat secara spesifik masa remaja berada pada usia 12-18 tahun. Menurut Robert J. Havighurst (Desmita, 2014:25) juga mengemukakan bahwa usia 12-18 tahun merupakan siswa yang sedang melalui masa remaja atau dapat disebut dengan adolescene. Remaja memiliki tugas perkembangan tertentu sesuai rentang usia. Dalam hal ini, secara garis besar bila siswa mampu menyelesaikan tugas perkembangannya maka dalam kehidupan selanjutnya peluang siswa tersebut jika menemukan permasalahan tidak begitu berpengaruh dalam kehidupannya. Comenius (Desmita, 2014:23) berpendapat bahwa di usia 12-18 tahun merupakan masa pengembangan daya pikir dibawah pendidikan menengah. Menurut Leulla Cole (Jahja, 2011:238) tugas perkembangan yang harus diselesaikan oleh remaja antara lain yaitu, 1) Kematangan sosial; 2) Pemantapan minat-minat hetero seksual; 3) Emansipasi dari kontrol keluarga; 4) Kematangan intelektual; 5) Memilih pekerjaan; 6) Menggunakan waktu senggang secara tepat; 7) Memiliki falsafat hidup; 8) Identifikasi diri.

Berkaitan dengan tugas perkembangan diatas maka pemerintah telah menyiapkan kurikulum yang tepat untuk mendukung terlaksananya tugas perkembangan siswa. Saat ini sistem pembelajaran yang dianut oleh sekolah di Indonesia menggunakan kurikulum 2013 atau K13, sebagaimana dijelaskan dalam Peraturan Pemerintah No. 32 Tahun 2013 tentang perubahan atas peraturan pemerintah nomor 19 Tahun 2005 tentang standar nasional pendidikan, dimana kurikulum ini memiliki 3 (Tiga) kriteria penilaian diantaranya kriteria mengenai kualifikasi kemampuan lulusan yang mencakup sikap, pengetahuan, dan keterampilan. Dari hal tersebut siswa diharapkan dapat membentuk diri menjadi pribadi yang matang dikemudian waktu. Pada kenyataannya, situasi di lapangan kurang sesuai dengan apa yang diharapkan pemerintah dalam mencapai tugas perkembangan remaja. Berdasarkan hasil observasi di kelas bersamaan dengan penyebaran Angket Kebutuhan Peserta Didik (AKPD) pada tanggal 26 Maret hingga 11 April 2019, peneliti mendapati siswa yang sedang mengerjakan tugas rumah pada mata pelajaran yang akan berlangsung setelah pemberian layanan Bimbingan dan Konseling dimana tugas itu seharusnya dikerjakan dirumah. Selajutnya peneliti mendapatkan hasil analisis dari Angket Kebutuhan Peserta Didik (AKPD) yang telah disebarkan di SMA Negeri 11 Semarang pada tanggal 26 Maret hingga 11 April 2019, tepatnya di kelas X IPA terdapat butir item yang memiliki tingkat pemilihan yang tinggi oleh siswa yaitu "Saya masih sering menunda-nunda tugas sekolah/pekerjaan rumah (PR)" item tersebut dapat dirincikan sebagai berikut X IPA 1 sebanyak 3,98\% atau 29 siswa, X IPA 2 sebanyak 4,24\% atau 23 siswa, X IPA 3 sebanyak $3,62 \%$ atau 30 siswa, X IPA 4 sebanyak $3,55 \%$ atau 32 siswa, X IPA 5 sebanyak $4,27 \%$ atau 33 siswa, X IPA 6 sebanyak 3,62\% atau 30 siswa, X IPA 7 sebanyak 4,24\% atau 26 siswa. Jika hasil keseluruhan di prosentasekan dari 7 (tujuh) kelas maka akan mendapatkan nilai $81 \%$ atau sebanyak 203 dari 252 siswa, dimana hasil ini tergolong pada kategori "Tinggi". Selanjutnya untuk memperkuat data yang didapatkan dari Angket Kebutuhan Peserta Didik (AKPD) dan observasi di kelas mengenai tugas yang sedang dikerjakan tersebut, peneliti juga melakukan wawancara langsung dengan guru BK pada tanggal 15 April 2019. Wawancara ini dilakukan di ruang BK yaitu dengan koordinator BK dan guru BK, dimana hasil yang didapatkan ternyata memang sesuai dengan Angket Kebutuhan Peserta Didik (AKPD) yaitu permasalahan tentang belajar. Selanjutnya peneliti juga melakukan wawancara kepada siswa untuk memastikan permasalahan apa yang sebenarnya terjadi berkaitan dengan pembelajaran, wawancara ini dilaksanakan pada tanggal 15 April 2019. Dari wawancara tersebut siswa memberikan alasan mengapa terdapat permasalahan tentang belajar, yaitu tugas yang diterima terlalu banyak sehingga siswa mengalami kesulitan mengatur waktu dan menyebabkan tugas dikerjakan dikemudian hari, tidak senang dengan guru tertentu karena tugas terlalu banyak, dan situasi pembelajaran di SMP dengan 
SMA berbeda karena begitu pulang sekolah siswa sudah merasa lelah. Namun dari hasil analisis Angket Kebutuhan Peserta Didik (AKPD) yang didapatkan, peringkat pertama permasalahan secara kolektif tertinggi adalah item "Saya merasa kesulitan dalam memahami pelajaran tertentu" yang memiliki prosentase sejumlah $87 \%$. Bila di telusuri lebih lanjut, penyebab permasalahan tersebut dikarenakan siswa sering menunda tugas. Dimana tindakan ini memberikan pengaruh akademik kepada siswa, dari item tersebut siswa sulit memahami pelajaran karena sering menunda tugas.

Dari hasil observasi dan wawancara diatas dapat disimpulkan bahwa sebagian besar siswa masih sering menunda dalam menyelesaikan tugas, hal ini dapat diartikan bahwa sikap prokrastinasi akademik siswa tergolong tinggi. Menurut Fauziah (2015) prokrastinasi adalah lebih suka melakukan tugasnya besok dibanding menyelesaikannya hari ini. Orang yang melakukan prokrastinasi disebut sebagai prokrastinator. Prokrastinasi adalah menunda dengan sengaja kegiatan yang diinginkan walaupun mengetahui bahwa penundaannya dapat menghasilkan dampak buruk. Menurut Muyana (2018) Prokrastinasi akademik dipahami sebagai suatu perilaku yang menjadi kebiasaan yang tidak efektif dan cenderung ke arah negatif dalam menunda-nunda pekerjaan. Prokrastinasi yang berkepanjangan tentu dapat mengganggu proktivitas individu dan dapat mengganggu kondisi individu secara psikis. Menurut Ghufron (2017:150) menjelaskan prokrastinasi akademik terjadi karena siswa memiliki perasaan tidak senang atau tidak nyaman terhadap tugas yang telah diberikan, prokrastinasi yang dimaksudkan dalam hal ini adalah prokrastinasi akademik yang berkaitan dengan siswa SMA. Ferarri (1995:3) mendefinisikan prokrastinasi akademik merupakan tindakan atau perilaku yang kompleks, bahkan sering kali bersifat kronis kepada individu yaitu menentang pemberian penjelasan atau perintah yang diberikan. Istilah prokrastinasi berasal dari bahasa latin yaitu Procrastination yang memiliki awalan "Pro" berarti dorongan maju atau bergerak maju dan "Crastinus" yang berarti "Keputusan hari esok" atau bila di gabungkan menjadi sebuah kalimat "menunda aktivitas hingga hari esok ataupun hari berkutnya" Ghufron (2017:150). Selanjutnya Ferarri (1995:1) mengungkapkan bahwa prokrastinasi akademik memiliki dampak negatif diantaranya jika siswa atau mahasiswa sering melakukan prokrastinasi maka akan banyak waktu yang terbuang secara sia-sia, tugas menjadi terbengkalai bahkan menjadi tidak maksimal karena tidak tepat waktu dan menghilangkan kesempatan serta peluang yang ada.

Prokrastinasi tersebut disebabkan oleh tingkah laku siswa atau Behaviour. Maka dari itu peneliti ingin memberikan layanan berupa bimbingan kelompok. Bimbingan kelompok adalah suatu cara memberikan bantuan (bimbingan) kepada individu (siswa) melalui kegiatan kelompok dengan tujuan yaitu untuk pengembangan kemampuan sosialisasi, mendorong pengembangan perasaan, pikiran, persepsi wawasan dan sikap yang menunjang perwujudan tingkah laku yang efektif serta mencegah timbulnya masalah pada siswa atau bersifat Preventif (Tohirin, 2015:165-166). Alasan peneliti menggunakan layanan bimbingan kelompok dikarenakan lebih efektif berkaitan jumlah siswa yang mengikuti kegiatan tidak sebanyak bimbingan klasikal, hal ini di dasari oleh hasil observasi yang dilakukan pada tanggal 26 Maret hingga 15 April terdapat permasalahan yang memiliki tingkat prosentase tergolong tinggi yaitu pada bidang belajar tepatnya prokrastinasi akademik atau siswa sering menunda tugas. Untuk mendukung layanan bimbingan kelompok ini, peneliti menggunakan teknik Self-Management yang bertujuan untuk mengurangi sikap prokrastinasi akademik. Menurut Ratna (2013:63) teknik self-management memiliki kelebihan, yaitu: Mempelajari tingkah laku yang lebih efektif, siswa menjadi lebih mandiri dan meningkatkan kepercayaan diri dalam mengembangkan perilaku yang lebih baik. Dengan adanya kelebihan tersebut maka peneliti berharap agar siswa mampu mencapai tujuan yang di tetapkan dengan cara mengikuti serangkaian proses layanan bimbingan kelompok yang diberikan oleh peneliti tepatnya adalah mengurangi sikap prokrastinasi akademik.

Sedangkan penelitian terdahulu yang dilakukan oleh Harnes \& Aidha (2013), layanan bimbingan kelompok tersebut dapat memberikan perubahan perilaku kepada siswa. Selanjutnya, Sukadji (Ratna 2013:59) menyatakan bahwa dalam teknik self-management, siswa bertanggug jawab secara penuh atas keberhasilan pemberian layanan yang diberikan. 
Perubahan dapat terjadi jika siswa secara bersungguh-sungguh mengikuti proses kegiatan layanan, pemimpin kelompok merupakan pencetus gagasan, fasilitator yang membantu merancang program serta motivator bagi siswa.

Berdasarkan uraian sebelumnya maka peneliti bermaksud untuk melakukan penelitian yang berjudul "Pengaruh Layanan Bimbingan Kelompok dengan Teknik Self-Management terhadap Prokrastinasi Akademik siswa kelas XI IPA SMA N 11 Semarang".

\section{Metode}

Penelitian ini menggunakan metode true experiment design dengan model pretestposttest control group design, dengan adanya pretest dan posttest untuk mengetahui keadaan awal dan akhir kelompok eksperimen dan kelompok kontrol. Penelitian ini dilaksanakan di SMA N 11 Semarang. alasan peneliti melakukan penelitian di SMA N 11 Semarang yaitu di SMA N 11 Semarang ditemukan permasalahan prorastinasi akademik. Pada siswa kelas XI IPA penelitian dilaksanakan pada tanggal 23 September - 24 oktober 2019 pada sampel yang diambil secara random pada kelas XI IPA.

Populasi dalam penelitian ini adalah seluruh siswa kelas XI IPA SMA N 11 Semarang. Dalam penelitian ini pengambilan sampel dilakukan dengan teknik sampling cluster random sampling, yaitu pengambilan dilakukan secara random di dapatkan daerah/kelas XI IPA 4 dan XI IPA 5 dan didapatkan sampel 10 siswa kelas XI IPA 4 dan 10 sampel siswa kelas XI IPA 5 .

Teknik pengumpulan data yang digunakan dalam penelitian ini skala prokrastinasi akademik siswa digunakan untuk membandingkan skor sebelum mendapat perlakuan dengan setelah mendapat perlakuan mengalami peningkatan atau tidak.

Instrumen yang digunakan adalah sebuah skala psikologis prokrastinasi akademik, hasil uji coba dianalisis untuk mengetahui validitas, reliabilitas. Dari 40 item pernyataan terdapat 28 item pernyataan yang valid.

Analisis data yang dilakukan pada penelitian ini terdiri dari data awal dan data akhir. Analisis data awal dapat dilihat dari pretest sebelum diberi perlakuan menggunakan layanan bimbingan kelompok dengan teknik Self-management sudah dinormalitaskan dengan menggunakan uji lilifors. Kemudian untuk mengetahui pengaruh layanan bimbingan kelompok dengan teknik self management digunakan hipotesis Uji $t$ dan Uji-t.

\section{Hasil dan Pembahasan}

\section{a. Data Pre-test}

Perhitungan uji normalitas pada penelitian ini menggunakan uji lillifors dengan taraf signifikan $5 \%$. Kriteria dalam uji normalitas ini adalah jika $L o<\mathrm{L}_{\text {tabel }}$ maka data berdistribusi normal, sedangkan jika $L o>L_{\text {tabel }}$ maka data berdistribusi tidak normal dan perhitungan homogenitas pada penelitian ini menggunakan uji F. Berikut rekapitulasi hasil perhitungan normalitas data pre-test sampel berikut:

Tabel 1. Uji Normalitas Data Pre-test Prokrastinasi Akademik

\begin{tabular}{lccc}
\hline \multicolumn{1}{c}{ Kelas } & Lo & Ltabel & Kesimpulan \\
\hline Eksperimen & 0,199 & 0,258 & Berdistribusi normal \\
Kontrol & 0,184 & 0,258 & Berdistribusi normal \\
\hline
\end{tabular}

Berdasarkan Tabel 1 terlihat bahwa hasil perhitungan yang diperoleh dari nilai pre-test, maka berdasarkan uji normalitas diperoleh $L_{0}<L_{\text {tabel }}$ yaitu $0,199<0,285$ pada kelompok eksperimen dan $0,184<0,285$ pada kelompok kontrol pada signifikan $5 \%$ dengan $\mathrm{N} 10$, maka Ho diterima, Sehingga dapat disimpulkan bahwa data pre-test prokrastinasi akademik berdistribusi normal. 
Tabel 2. Uji Homogenitas Data Pre-test Prokrastinasi Akademik

\begin{tabular}{ccc}
\hline F Hitung & F Tabel & Kesimpulan \\
\hline 1,087 & 2,98 & Homogen \\
\hline
\end{tabular}

Berdasarkan uji homogenitas data pre-test pada Tabel 2 karena $\mathrm{F}$ hitung $<\mathrm{F}$ tabel yaitu $1,087<2,98$ maka Ho diterima. Sehingga dapat disimpulkan bahwa sampel berasal dari populasi yang sama atau homogen.

b. Data Post-test

Perhitungan uji normalitas pada penelitian ini menggunakan uji lilifors dengan taraf signifikan $5 \%$. Kriteria uji normalitas ini adalah jika $L o<L_{\text {tabel }}$ maka data berdistribusi normal dan perhitungan homogenitas pada penelitian ini menggunakan uji $\mathrm{F}$. Berikut rekapitulasi hasil perhitungan normalitas dan homogenitas data post-test sampel berikut:

Tabel 3. Uji Normalitas Data Post-test Prokrastinasi Akademik

\begin{tabular}{lccc}
\hline \multicolumn{1}{c}{ Kelas } & Lo & Ltabel & Kesimpulan \\
\hline Eksperimen & 0,186 & 0,258 & Berdistribusi normal \\
Kontrol & 0,172 & 0,258 & Berdistribusi normal \\
\hline
\end{tabular}

Berdasarkan Tabel 3 terlihat bahwa hasil perhitungan yang diperoleh dari skor posttest, maka berdasarkan uji normalitas diperoleh $\mathrm{L}_{0}<\mathrm{L}_{\text {tabel }}$ berdasarkan hasil post-test yaitu $0,186<0,285$ pada kelompok eksperimen dan 0,172<0,285 pada kelompok kontrol pada signifikan $5 \%$ dengan N 10, maka Ho diterima, Sehingga dapat disimpulkan bahwa data post-test efikasi diri berdistribusi normal.

Tabel 4.Uji Homogenitas Data Post-test Prokrastinasi Akademik

\begin{tabular}{ccc}
\hline F Hitung & F Tabel & Kesimpulan \\
\hline 0,616 & 2,98 & Homogen \\
\hline
\end{tabular}

Uji homogenitas varian dilakukan dua kelompok yaitu kelompok kontrol dan kelompok eksperimen. Menurut Arikunto (2010: 363) disamping pengujian terhadap normalitas, perlu kiranya peneliti melakukan pengujian terhadap variabel sampel-sampel yang diambil dari populasi yang sama. Dengan demikian, maka ditinjau dari segi waktu, $F_{\text {test }}$ (uji F) lebih efisien untuk uji homogenitas varians. Pengujian homogenitas varians dapat dilakukan dengan menggunakan uji $\mathrm{F}$ dengan berikut:

$$
F=\frac{s^{2} b}{S^{2} k} \quad S^{2}=\frac{\sum x^{2}-\frac{(\Sigma X)^{2}}{N}}{N-1}
$$

Keterangan :

$$
S^{2} b=\text { variansi besar }
$$

$S^{2} k=$ variansi kecil

Nilai $F_{\text {hitung }}$ yang diperoleh kemudian akan dibandingkan dengan Ftabel pada taraf signifikan $5 \%$. Kedua varians dikatakan homogen apabila $\mathrm{F}_{\text {hitung }}<\mathrm{F}_{\text {tabel. }}$.

Berdasarkan uji homogenitas data post-test pada tabel di atas karena $\mathrm{F}$ hitung $<\mathrm{F}$ tabel yaitu 1,616 <2,98 maka Ho diterima. Sehingga dapat disimpulkan bahwa sampel berasal dari populasi yang sama atau homogen. 
Tabel 5. Hipotesis Uji T

\begin{tabular}{ccccc}
\hline \multicolumn{5}{c}{ Tabel Persiapan Uji T } \\
\hline No & $\mathbf{X}_{2 \text { (kontrol) }}$ & $\mathbf{X}_{1 \text { (eksperimen) }}$ & $\boldsymbol{X}_{\mathbf{2}}^{2}$ & $\boldsymbol{X}_{\mathbf{1}}^{\mathbf{2}}$ \\
Subjek & 64 & 69 & 4096 & 4761 \\
1 & 73 & 55 & 5329 & 3025 \\
2 & 63 & 65 & 3969 & 4225 \\
3 & 72 & 59 & 5184 & 3481 \\
4 & 75 & 60 & 5625 & 3600 \\
5 & 70 & 55 & 4900 & 3025 \\
6 & 74 & 50 & 5476 & 2500 \\
7 & 73 & 60 & 5329 & 3600 \\
8 & 71 & 65 & 5041 & 4225 \\
9 & 65 & 60 & 4225 & 3600 \\
10 & $\mathbf{7 0 0}$ & $\mathbf{5 9 8}$ & $\mathbf{4 9 1 7 4}$ & $\mathbf{3 6 0 4 2}$ \\
\hline Jumlah & $\mathbf{X}_{\mathbf{2} \text { (kontrol) }}$ & $\mathbf{X}_{\mathbf{1}}$ (eksperimen) & $\boldsymbol{X}_{\mathbf{2}}^{2}$ & $\boldsymbol{X}_{\mathbf{1}}^{2}$ \\
\hline Kode & & & &
\end{tabular}

Dapat diketahui bila tingkat kesalahan $5 \%$ dengan $\mathrm{dk} 18$, maka harga $t_{\text {tabel }}=2,101$. (dk $=n 1+n 2-2=10+10-2=18)$. Ternyata harga $t_{\text {hitung }}= \pm 4,561$ jauh lebih besar daripada $t_{\text {tabel }}$ 2,101 . Dengan demikian dapat ditarik kesimpulan keputusan uji hipotesis, $t_{\text {hitung }}>t_{\text {tabel }}$, maka Ho ditolak dan Ha diterima. Oleh karena itu hipotesisnya berbunyi bahwa ada pengaruh bimbingan kelompok dengan teknik self-management terhadap prokrastinasi akademik siswa kelas XI IPA SMA Negeri 11 Semarang.

\section{Simpulan dan Saran}

Berdasarkan Setelah diberikan treatment bimbingan kelompok dengan teknik selfmanagement pada kelompok eksperimen tingkat prokrastinasi akademik menurun dari 70,3 menjadi 59,8 terjadi penurunan sebesar 10,5. Sedangkan pada kelompok kontrol dari 70,1 menjadi 70 terjadi penurunan sebesar 0,1. Selisih antara kelompok eksperimen dan kelompok kontrol yaitu 10,4. Hasil analisis data menunjukan bahwa ada perbedaan antara kelompok eksperimen yang diberikan treatment berupa layanan bimbingan kelompok dengan menggunakan teknik self-management dan kelompok kontrol yang tidak diberikan treatment self-management.

Analisis hasil data rata-rata perindikator dari kelompok eksperimen dan kelompok kontrol terdapat perbedaan. Hasil yang diperoleh kelompok eksperimen perindikator skor rata-rata 14,95, sedangkan untuk kelompok kontrol skor rata-rata 17,5. Dari hasil tersebut dapat disimpulkan bahwa terdapat perbedaan yang signifikan antara kelompok eksperimen dan kelompok kontrol, dengan jumlah selisih sebesar 2,55. Adapun selisih dari masingmasing indikator antara lain: pada indikator 1 (Penundaan untuk mulai dan menyelesaikan tugas) terdapat selisih 1,9 point, indikator II (Keterlambatan dalam mengerjakan tugas) terdapat selisih 3,8 point, indikator III (Kesenjangan waktu antara rencana dan kinerja aktual) terdapat selisih 2,5 point, indikator IV (Melakukan aktivitas yang lebih menyenangkan) terdapat selisih 2 point.

Dari perhitungan uji hipotesis diatas diperoleh $t_{\text {hitung }}= \pm 4,561$. Selanjutnya dikonsultasikan dengan ( $\left.\mathrm{dk}=\mathrm{n}_{1}+\mathrm{n}_{2}-2=10+10-2=18\right)$ dan taraf signifikan $5 \%$ dengan $\mathrm{t}_{\text {tabel }}$ $=2,101$, sehingga $t_{\text {hitung }}>t_{\text {tabel }} \pm 4,561>2,101$. Dengan demikian maka Ho ditolak dan Ha diterima. Oleh karena itu hipotesis yang berbunyi "ada pengaruh layanan bimbingan kelompok dengan teknik self-management terhadap prokrastinasi akademik siswa kelas XI IPA SMA Negeri 11 Semarang Tahun ajaran 2019/2020" diterima kebenarannya.

Berdasarkan hasil diatas maka terbukti bahwa ada pengaruh layanan bimbingan kelompok dengan teknik self-management terhadap prokrastinasi akademik siswa kelas XI IPA SMA Negeri 11 Semarang. Dengan diberikannya layanan bimbingan kelompok dengan 
teknik self-management maka siswa dapat mengurangi hal yang negatif kemudian merubah ke arah positif dalam hal ini berkaitan dengan prokrastinasi akademik, yaitu dengan tahapan memilih tujuan, menerjemahkan tujuan dalam tingkah laku, monitoring pribadi, merancang rencana perubahan, mengevaluasi action plan. Dengan begitu siswa kedepannya diharapkan dapat mengatasi permasalahannya secara mandiri dan siswa dapat membuat keputusan untuk kebaikan dirinya sendiri.

Layanan bimbingan kelompok dengan teknik self-management adalah suatu bentuk kegiatan layanan yang diberikan kepada siswa melalui kegiatan kelompok, dalam kegiatan layanan tersebut dinamika kelompok harus terbentuk meliputi komunikasi antar siswa dan persamaan tujuan. Siswa yang berpartisipasi secara aktif akan mendapatkan manfaat bagi dirinya sendiri yaitu meliputi wawasan dan keterampilan guna menghadapi masalah yang dihadapi, serta penanganan permasalahan yang mungkin dihadapi di kemudian hari secara mandiri. Dalam kaitannya memanajemen diri yaitu, siswa dapat mengontrol perilaku yang seharusnya dilakukan dan tidak dilakukan. Perubahan yang terjadi dapat bersifat secara total namun semua tergantung dari siswa tersebut apakah mau melakuakan perubahan untuk menjadi lebih baik atau tidak berkaitan dengan cara memanajemen dirinya sendiri dalam hal akademik yaitu tentang prokrastinasi.

. Dalam pemberian teknik Self-Management, peneliti menggunakan tahapan yang dikemukakan oleh Waston dan Tharp (dalam Yusuf 2016:205) yaitu:

1) Memilih Tujuan, 2) Menterjemahkan tujuan-tujuan ke dalam tingkah-tingkah laku sasaran, 3) Monitoring Pribadi, 4) Merancang rencana perubahan, 5) Mengevaluasi action plan

Setelah diberikan layanan bimbingan kelompok dengan teknik self-management, indikator yang menunjukkan keberhasilan tertinggi adalah "penundaan untuk memulai dan menyelesaikan tugas". Menurut Ferarri, dkk (dalam Ghufron 2017:158) siswa yang melakukan prokrastinasi mengetahui jika tugas yang dihadapi harus segera diselesaikan, akan tetapi siswa tersebut menunda untuk mengerjakan hingga tuntas dikarenakan sebelumnya sudah mengerjakan tetapi tidak sampai selesai.

Berdasarkan hasil penelitian yang telah peneliti lakukan ternyata layanan bimbingan kelompok dengan teknik self-management dapat berpengaruh terhadap prokrastinasi akademik siswa kelas XI IPA SMA Negeri 11 Semarang.

\section{Daftar Pustaka}

Alamri, N. (2015). Layanan Bimbingan Kelompok Dengan Teknik Self Management Untuk Mengurangi Perilaku Terlambat Masuk Sekolah (Studi Pada Siswa Kelas X SMA 1 Gebog Tahun 2014/2015). Jurnal Konseling Gusjigang, 1(1). https://doi.org/10.24176/jkg.v1i1.259

Arikunto, S. (2009). Manajemen Penelitian. Jakarta: PT Rineka Cipta.

Arikunto, Suharsimi. (2010). Prosedur Penelitian Suatu Pendekatan Praktik. Jakarta: Rineka Cipta.

Asri, N. D. (2018). Prokrastinasi Akademik. Madiun: Unipma Press.

Burka, Jane B. \& Yuen, Lenora, M. (2008). Procrastination Why You Do It, What to Do About It Now. Cambridge: Da Capo Press

Davies, R. (2015). Industry 4.0. Digitalisation for productivity and growth. European Parliamentary Research Service, (September), 10.

Desmita. (2014). Psikologi Perkembangan Peserta Didik. Bandung: PT. Remaja Rosdakarya 
DS, Hartinah, S. (2019). Konsep Dasar Bimbingan Kelompok. Bandung: PT. Refika Aditama

Fauziah, Hana Hanifah. 2015. Fakor-Faktor yang Mempengaruhi Prokrastinasi Akademik pada Mahasiswa Fakultas Psikologi UIN Sunan Gunung Djati Bandung. Jurnal IImiah Psikologi Desember 2015, Vol. 2, No. 2, Hal: 123 - 132. Tersedia Pada: https://journal.uinsgd.ac.id/index.php/psy/article/view/453.

Ferrari, J. R., Johnson, J. L.,\& McCown, W. G.(1995). Procrastination And Task Avoidance (Theory, Research, And Treatment).New York: Plenum Press

Ghufron, M. N., \& S, Risnawita, R. (2017). Teori-Teori Psikologi. Yogyakarta: Ar-Ruz Media.

Gunarsa, D, Singgih. (2004). Konseling dan Psikoterapi. Jakarta: Gunung Mulia.

Harnes, N., \& Aidha, P. (2013). Kelompok Untuk Meningkatkan Motivasi Belajar Siswa Kelas VIII D SMP Negeri 1 Ngariboyo Nindia Harnes Prima Aidha. 03(01), 216-224.

Hartono \& Soedarmadji, B. (2014). Psikologi Konseling Edisi Revisi. Jakarta: Kencana

Jahja, Yudrik (2011). Psikologi Perkembangan. Jakarta: Kencana Prenadamedia Group.

Komalasari, G., dkk. (2018). Teori dan Teknik Konseling. Jakarta: PT.Indeks

MBA, Riduwan., \& Sunarto. (2007). Pengantar Statistika. Untuk penelitian Pendidikan, Sosial, Ekonomi, Komunikasi dan Bisnis. Bandung : Alfabeta

Muyana, Siti. 2018. Prokrastinasi Akademik Dikalangan Mahasiswa Program Studi Bimbingan dan Konseling. Jurnal Bimbingan dan Konseling 8 (1), 45 - 52. Tersedia Pada: http://e-journal.unipma.ac.id/index.php/JBK/article/view/1868.

Prayitno, dan Erman Amti. (2013). Dasar-Dasar Bimbingan \& Konseling. Jakarta: Rineka Cipta.

Prayitno, dkk. (2017). Layanan Bimbingan Kelompok dan Konseling Kelompok. Bogor: Ghalia Indonesia.

Ratna, Lilis. (2013). Teknik-Teknik Konseling. Yogyakarta: Deepublish.

Reza, J. (2010). Cerdas Mengelola Waktu untuk Mencapai Sukses. Yogyakarta: Andi Offest

Riansyah, H., Satrianta, H., \& Astriyaningsih, A. (2018). Bimbingan Kelompok Teknik Role Play Untuk Mereduksi Prokrastinasi Akademik Siswa. Jurnal Fokus Konseling, 4(1), 72. https://doi.org/10.26638/jfk.527.2099

Romlah, T. (2001). Teori dan Praktek Bimbingan Kelompok. Malang: Universitas Negeri Malang.

Sugiyono. (2015). Metodelogi Penelitian Pendidikan: Pendekatan Kuantitatif, Kualitatif, dan $R \& D$. Bandung: CV Alfabeta.

Sugiyono. (2016). Metode Penelitian Pendidikan: Pendekatan Kuantitatif, Kualitatif, dan $R N D$. Bandung: CV Alfabeta

Supardi. (2016). Dasar-dasar Metodelogi Penelitian Bimbingan dan Konseling. Yogyakarta: Andi Offset. 
Tohirin. (2015). Bimbingan Dan Konseling Di Sekolah Dan Madrasah (Berbasis Integasi). Jakarta: Rajawali Pers.

Yusuf, Syamsu., \& Nurhisan,. A. J. (2012). Landasan Bimbingan \& Konseling. Bandung: Remaja Rosdakarya.

Yusuf, Syamsu. (2016). Konseling Individual Konsep Dasar \& Pendekatan. Bandung: PT Refika Aditama. 